\title{
An assessment of vessel traffic patterns in the Northwestern Hawaiian Islands between 1994 and 2004
}

\author{
Erik C. Franklin * \\ Hawai'i Institute of Marine Biology, University of Hawai'i, P.O. Box 1346, Kaneohe, Hawai'i 96744, United States
}

On June 15, 2006, the United States President George $\mathrm{W}$. Bush signed a proclamation that established the largest coral reef marine reserve in the world, the Northwestern Hawaiian Islands Marine National Monument (NWHI MNM). The NWHI MNM protects a chain of islands and atolls that encompass approximately $360,000 \mathrm{~km}^{2}$, including $11,650 \mathrm{~km}^{2}$ of relatively undisturbed coral reef habitat that support more than 3000 species, a quarter of which are endemic (NOAA, 2006). To evaluate the attainment of the Monument's management goals through time, baseline information was presented on the historic and recent distributions and characteristics of natural resources, environmental conditions, and anthropogenic activities in the NWHI. Although these studies were abundant enough to merit an entire issue of Atoll Research Bulletin (DiNardo and Parrish, 2006), they did not assess the potential threats posed by maritime traffic, an important anthropogenic activity that could significantly impact the protected marine resources of the NWHI. To date, documented vessel impacts to coral reefs range from physical damage caused by running aground (Hatcher, 1984; Gittings et al., 1993) and anchoring (Rogers and Garrison, 2001) to invasive species introductions (Godwin and Eldredge, 2001; Godwin, 2003; Godwin et al., 2004) and marine pollution such as oil spills (Keller and Jackson, 1993), but the magnitude and spatial distribution of these threats to the NWHI was unknown because of the paucity of information on vessel traffic patterns there.

Due to the size and remoteness of the NWHI, only anecdotal information regarding the activities and attributes of maritime traffic was previously available. Although commercial and research activities occurred in the NWHI for approximately a century (Grigg, 2006; Pooley and Pan, 2006), no quantitative estimation of vessel activity was reported. Unlike some marine management areas adjacent to the continental United States, the NWHI MNM has not had access to an automatic identification system (AIS) or radar array to facilitate the tracking and identification of vessel traffic and provide information on past or present vessel activity (Sean Corson, NWHI MNM, personal communication). The aim of this paper was to provide a baseline of recent activity and identify high traffic corridors, the location of vessels and their attributes in the current

\footnotetext{
* Tel.: +1 808440 8607; fax: +1 8082367443.

E-mail address: erik.franklin@hawaii.edu
}

boundary of the NWHI MNM from 1994 to 2004. This study represents the first effort to provide a quantitative estimation of vessel traffic to inform management strategies of the MNM related to this anthropogenic activity.

Spatial patterns and characteristics of vessel traffic in the Northwestern Hawaiian Islands were examined from January 1994 to December 2004 with information from the International Comprehensive Ocean-Atmosphere Data Set (ICOADS, 2006), Western Pacific Fishery Management Council (WESPAC, 2006) and the United States Coast Guard (USCG, 2006). A grid with $0.2^{\circ}$ by $0.2^{\circ}$ cells of the NWHI was created between $35^{\circ} \mathrm{N}, 175^{\circ} \mathrm{E}, 15^{\circ} \mathrm{N}$, and $155^{\circ} \mathrm{W}$ in a non-projected geographic coordinate system using ArcGIS 9.1. The locations of 6711 vessel reports from ICOADS (2006) were provided in latitude and longitude and plotted onto the NWHI grid within the current boundary of the NWHI MNM. A count of vessel reports in each grid cell was summed and displayed as a color scale gradient using a modified natural breaks algorithm (Jenks, 1977). Vessel reports from ICOADS (2006) were consolidated to vessel days to standardize the unit of time spent in the NWHI using SAS 9.1.3. Standardization was necessary because the frequency of reports from different vessels varied between every 6-24 h. From WESPAC (2006), the number of fishing vessels in the NWHI commercial bottomfish fishery fleet and their reported fishing days were included in the analysis. Using the vessel call signs provided with ICOADS, data on a vessel's length, tonnage, service, and flag were downloaded from the US Coast Guard Maritime Information Exchange Port State Information Exchange (USCG, 2006) and merged with the vessel location data. Summary statistics of vessel characteristics were tabulated for vessels that had a call sign match in both the ICOADS and USCG data sets.

A total of 545 vessels reported from inside the current boundary of the NWHI MNM between 1994 and 2004. Vessel traffic operated primarily through two corridors, one along the NWHI island chain consisting primarily of vessels that operated out of the Main Hawaiian Islands (MHI) and another across the NWHI comprising vessels that transited between Pearl and Hermes Atoll and Lisianski Island (Fig. 1). The corridor across the NWHI MNM appeared to be used by vessels deviating from or navigating to the "great circle route" at $30^{\circ} \mathrm{N}$. While most (i.e., $59.8 \%$ ) of the vessels reported from the NWHI MNM were freighters, there were also a small number of tankers $(6.1 \%)$, fishing vessels $(3.1 \%)$, and research vessels $(3.1 \%)$ 
(Table 1). The NWHI commercial bottomfish fishing vessels spent the most cumulative time of any vessel type with 7429 vessel days (which is approximately $75 \%$ of the total vessel days reported) in the NWHI MNM (Table 1). Research vessels $(12.7 \%)$ and freighters $(8.1 \%)$ spent the next most vessel days in the NWHI MNM. Total intraannual vessel reports were consistently greater in spring and summer (March-September) than in fall and winter (i.e., October-February) but the commercial vessel traffic transiting between Pearl and Hermes Atoll and Lisianski Island was greater during fall and winter. Total interannual vessel activity in the NWHI MNM decreased over the study period from a mean of about 1000 annual vessel days between 1994 and 1998 to approximately 825 annual vessel days between 1999 and 2004. For ICOADS vessels with attribute data in the USCG database, the mean vessel length was $178 \mathrm{~m}$ (with s.d. $=78 \mathrm{~m}$ for data available from 332 of the 547 vessels) and mean gross vessel tonnage was $34,512 \mathrm{~m}$ tons (with s.d. $=27,951 \mathrm{~m}$ tons for data available from 262 of the 547 vessels). Vessels were flagged under 29 different countries with Panama, Liberia, Japan, and Germany as the most common non-US flags.

One primary intent of the NWHI MNM is to serve as a sentinel research site isolated from major local or regionalscale anthropogenic disturbances to examine the effects of global-scale threats to coral reefs such as thermal stress (McWilliams et al., 2005; Berkelmans and van Oppen, 2006), marine diseases (Kim et al., 2005) and seawater acidification (Orr et al., 2005; Guinette et al., 2006). Critical to the role of the MNM as a sentinel research site is the assessment of historic and current levels of anthropogenic activity and their associated impacts on marine ecosystems. While the relative remoteness of the NWHI has contributed to the near pristine reef conditions, high abundance
Table 1

The number of vessels and number of vessel days by vessel type spent within the current boundaries of the NWHI MNM between 1994 and 2004

\begin{tabular}{llllll}
\hline Type & \multicolumn{2}{l}{ Vessels } & & \multicolumn{2}{c}{ Vessel days } \\
\cline { 2 - 3 } & $(\#)$ & $(\%)$ & & $(\#)$ & $(\%)$ \\
\hline Fishing vessel & 17 & 3.1 & & 7429 & 74.6 \\
Freight ship & 326 & 59.8 & & 809 & 8.1 \\
Passenger ship & 4 & 0.7 & 8 & 0.1 \\
Research vessel & 17 & 3.1 & 1260 & 12.7 \\
School ship & 5 & 0.9 & 20 & 0.2 \\
Tank ship & 33 & 6.1 & 72 & 0.7 \\
Towing vessel & 3 & 0.6 & 10 & 0.1 \\
Unclassified & 7 & 1.3 & 32 & 0.3 \\
Unreported & 133 & 24.4 & 322 & 3.2 \\
Total & 545 & 100.0 & 9962 & 100.0 \\
\hline
\end{tabular}

Data sources: ICOADS (2006), USCG (2006), WESPAC (2006).

and endemism of life found there (DeMartini and Friedlander, 2004), the geographic extent of the island chain also presents difficult logistical challenges for the evaluation of regional-scale anthropogenic activities. For example, the management precursor to the NWHI MNM, the NWHI Coral Reef Ecosystem Reserve, operated from 2000 to 2005 with merely anecdotal information regarding vessel traffic and thus there was assumed to be "little to no vessel activity" in the NWHI (Sean Corson, NWHI MNM, personal communication). In contrast, this study illustrates two primary corridors of vessel activity in the NWHI from 1994 to 2004 and provides information on the distribution and composition of these vessels that can be used to facilitate an efficient allocation of resources for surveillance, enforcement, and response.

A risk management strategy for vessel impacts in the NWHI MNM should address the suite of threats posed

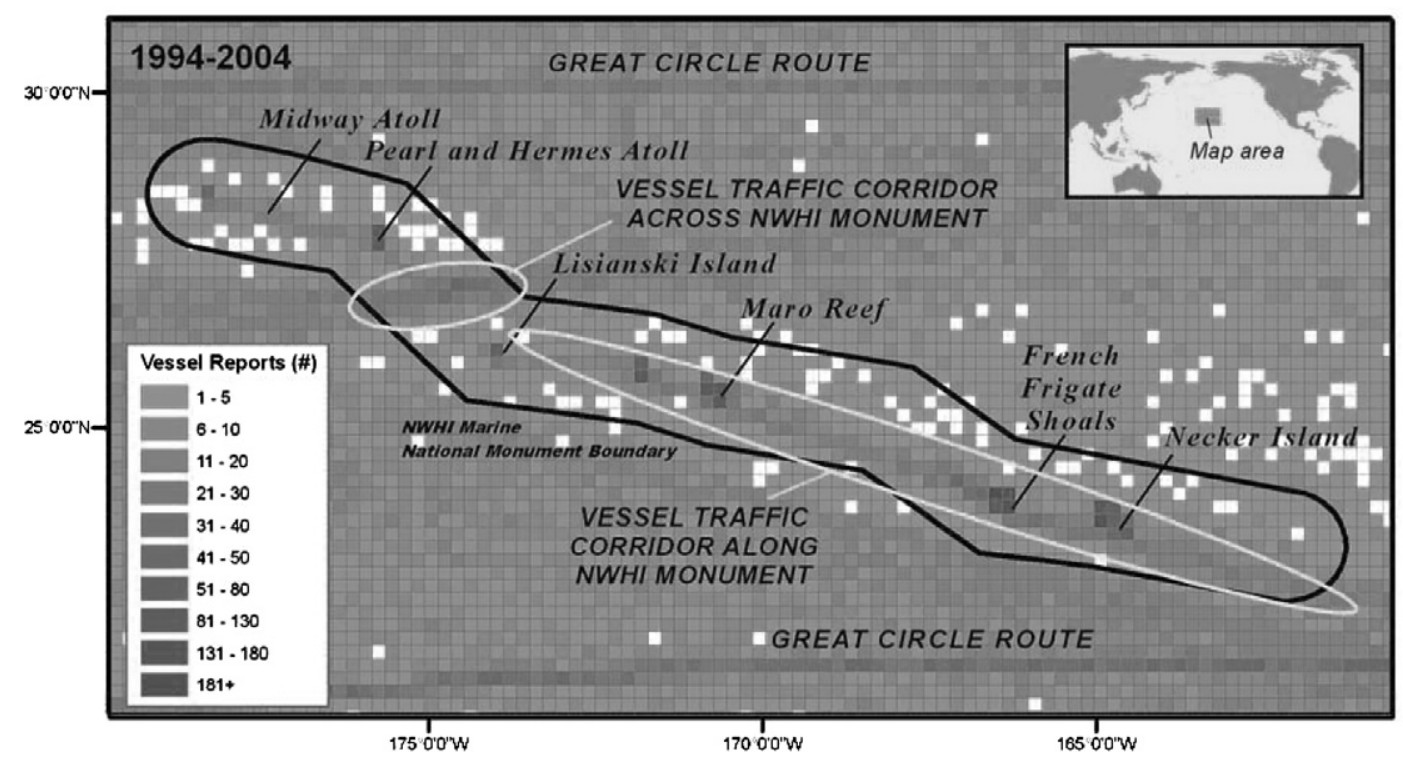

Fig. 1. Spatial distribution of vessels reported near and within the current boundaries of the NWHI MNM from 1994 to 2004 . Two primary vessel corridors in the NWHI MNM are noticeable: one along the island chain and another that transits across the chain between Pearl and Hermes Atoll and Lisianski Island. Grid cells are $0.2^{\circ}$ by $0.2^{\circ}$. 
by the two maritime corridors. The vessels transiting across the chain were primarily large $(\sim 600 \mathrm{ft})$, non-US-flagged commercial freighters and tankers utilizing the corridor as a pathway between the $20^{\circ} \mathrm{N}$ and $30^{\circ} \mathrm{N}$ "great circle routes". From this maritime traffic, the shallow marine environments of Pearl and Hermes Atoll and Lisianski Island are vulnerable to vessel groundings and associated oil spills, but may experience a lesser risk of invasive species introductions since the vessels are in transit. Vessel activity along the chain was primarily commercial fishing vessels, research vessels, or commercial vessels operating from the Main Hawaiian Islands. The threat of marine pollution and contaminant discharge or species introduction would seem to be greater for these vessels since they spend extended periods of time around the atolls and islands in the NWHI MNM. In particular, most of the 343 alien marine and brackish water species in Hawaiian waters are believed to have arrived via vessel hull fouling, solid ballast, or ballast water (DeFelice et al., 2001; Eldredge and Carlton, 2004), thus, the effects of species introduction from hull fouling, sea chests, or anchors on the MHI vessels may represent an acute threat to the NWHI. Unlike vessel impacts from pollution or oil spills where containment and restoration actions can have ameliorative effects, non-indigenous species introductions are often irreversible (IUCN, 2006). In contrast to the threats of the large commercial vessels that transit across the NWHI and bypass Hawaiian ports, the potential impacts of the MHI vessels can be significantly minimized by the regulatory requirements of the NWHI MNM including entry-by-permit, nearshore no-discharge rules, and periodic hull inspections. In addition, the NWHI bottomfish fishery will be closed in 2011 thus eliminating a significant component of the MHI vessel traffic.

The information used for this study represents the best available data from sources whose primary focus was not the examination of vessel traffic patterns. For example, the ICOADS included only information from the Voluntary Observing Ship Program (for details, see link in ICOADS, 2006); these data represented a minimum level of vessel activity in the study domain and thus, the relationship between the number of "vessel reports" and the absolute number of vessels that were present during the study period is unknown. Nonetheless, these data provide a synopsis of spatial patterns that may be assumed to be representative of vessel activities. There were also several additional vessel types which may have operated in the NWHI not addressed by this study: recreational vessels, commercial longline fishing vessels, military vessels, and illegal (US and non-US) fishing vessels. Potential sources of additional data to augment this study include satellite imagery, archived data from US Coast Guard NWHI survey flights, or declassified surveillance from the Department of Defense or Office of Homeland Security. The inclusion of additional data might alter but should simply refine the general results of this study.
Overlooked threats can contribute to unfulfilled management objectives for marine protected areas (Jameson et al., 2002). The spatial delineation and characterization of the two maritime corridors presented here provides a baseline of previously undescribed vessel threats to the marine resources of the NWHI. The utility of this information for the management of the region has already been demonstrated; for example, an earlier version of this work was used for a review of the NWHI Area-to-be-Avoided designation by the International Maritime Organization (Sean Corson, NWHI MNM, personal communication). Future efforts to monitor vessel traffic in the NWHI MNM would benefit greatly from the delivery of near-realtime or realtime information from a suite of technologies such as satellite imagery, high frequency surface radar, or remote AIS receivers. A continued decrease in vessel traffic, especially with the elimination of the NWHI bottomfish fishery in 2011, and the enforcement of proactive regulatory measures should further minimize the threat of vessel impacts in the NWHI MNM and support the long-term sustainability of the unique marine communities of the Northwestern Hawaiian Islands.

\section{Acknowledgements}

This work was funded by NMSP MOAs 2005-008/6682, 2005-008/6944 (Amend.001) and 2005-008 (Amend.002)/ 7189 with the NOAA Northwestern Hawaiian Islands Marine National Monument. I wish to thank Scott Godwin, Phillip McGillivary, and an anonymous referee who provided comments to improve the manuscript and Dave Whitehill and Mark Guagliardo for assistance with data discovery and preparation. This article is Hawai'i Institute of Marine Biology contribution 1289.

\section{References}

Berkelmans, R., van Oppen, M.J.H., 2006. The role of zooxanthellae in the thermal tolerance of corals: a'nugget of hope' for coral reefs in an era of climate change. Proceedings of the Royal Society B: Biological Sciences 273 (1599), 2305-2312.

DeFelice, R.C., Eldredge, L.G., Carlton, J.T., 2001. Nonindigenous marine invertebrates. In: Eldredge, L.G., Smith, C.M. (Eds.), A Guidebook of Introduced Marine Species in Hawaii. Bishop Museum Technical Report 21, pp. B1-B60.

DeMartini, E.E., Friedlander, A.M., 2004. Spatial patterns of endemism in shallow reef fish populations of the Northwestern Hawaiian Islands. Marine Ecology Progress Series 271, 281-296.

DiNardo, G., Parrish, F.A. (Eds.), 2006. Proceedings of Third NWHI Scientific Symposium. Atoll Research Bulletin, 543, pp. 1-579.

Eldredge, L.G., Carlton, J.T., 2004. Hawai'i marine bioinvasions: a preliminary assessment. Pacific Science 56 (2), 211-212.

Gittings, S.R., Bright, T.J., Hagman, D.K., 1993. The M/V Wellwood and other large vessel groundings: coral reef damage and recovery, pp. 174-180. In Global Aspects of Coral Reefs: Health, Hazards, and History. Rosenstiel School of Marine and Atmospheric Science, Univ. of Miami, $420 \mathrm{pp}$.

Godwin, L.S., 2003. Hull fouling of maritime vessels as a pathway for marine species invasions to the Hawaiian Islands. Biofouling 19 (Suppl.), 123-131. 
Godwin, L.S., Eldredge, L.G., 2001. South Oahu Marine Invasions Shipping Study. Bishop Museum Technical Report No. 20.

Godwin, L.S., Eldredge, L.G., Gaut, K., 2004. The assessment of hull fouling as a mechanism for the introduction and dispersal of marine alien species in the Main Hawaiian Islands. Bishop Museum Technical Report No. 28.

Grigg, R.W., 2006. The history of marine research in the Northwestern Hawaiian Islands: lessons from the past and hopes for the future. Atoll Research Bulletin 543, 13-22.

Guinette, J.M., Orr, J., Cairns, S., Freiwald, A., Morgan, L., George, R., 2006. Will human-induced changes in seawater chemistry alter the distribution of deep-sea scleractinian corals? Frontiers in Ecology and the Environment 4 (3), 141-146.

Hatcher, B.G., 1984. A maritime accident provides evidence for alternate stable states in benthic communities on coral reefs. Coral Reefs 3 (4), 199-204.

Global Invasive Species Database (IUCN). <http://www.issg.org/database/welcome $>$ (accessed 27.10.2006).

International Comprehensive Ocean-Atmosphere Data Set (ICOADS), 2006. ICOADS home page. $<$ http://icoads.noaa.gov $>$ (accessed 13.02.2006)

Jameson, S.C., Tupper, M.H., Ridley, J.M., 2002. The three screen doors: can marine "protected" areas be effective? Marine Pollution Bulletin 44, 1177-1183.

Jenks, G.F., 1977. Optimal data classification for choropleth maps. Occasional Paper No. 2. University of Kansas, Department of Geography, Lawrence, Kansas.

Keller, B.D., Jackson, J.B.C. (Eds.), 1993. Long-term Assessment of the Oil Spill at Bahia Las Minas, Panama, Synthesis Report, vol. II: Technical Report Part 1\&2. OCS Study MMS 93-0048. US Dept. of Int., Minerals Management Service, Gulf of Mex. OCS Region. Off., New Orleans, LA, 1008 pp.
Kim, K., Dobson, A.P., Gulland, F.M.D., Harvell, C.D., 2005. Diseases and the conservation of marine biodiversity. In: Norse, E.A., Crowder, L.B. (Eds.), Marine Conservation Biology. Island Press, 470 pp.

McWilliams, J.P., Cote, I.M., Gill, J.A., Sutherland, W.J., Watkinson, A.R., 2005. Accelerating impacts of temperature-induced coral bleaching in the Caribbean. Ecology 86 (8), 2055-2060.

National Oceanic and Atmospheric Administration (NOAA), 2006. Northwestern Hawaiian Islands Proposed National Marine Sanctuary Draft Environmental Impact Statement and Management Plan, vol. II. Honolulu, HI, 375 pp.

Orr, J.C., Fabry, V.J., Aumont, O., Bopp, L., Doney, S.C., Feely, R.A., Gnanadesikan, A., Gruber, N., Ishida, A., Joos, F., Key, R.M., Lindsay, K., Maier-Reimer, E., Matear, R., Monfray, P., Mouchet, A., Najjar, R.G., Plattner, G.-K., Rodgers, K.B., Sabine, C.L., Sarmiento, J.L., Schlitzer, R., Slater, R.D., Totterdell, I.J., Weirig, M.-F., Yamanaka, Y., Yool, A., 2005. Anthropogenic ocean acidification over the twenty-first century and its impact on calcifying organisms. Nature 437, 681-686.

Pooley, S.G., Pan, M., 2006. Economic research on the NWHI - a historical perspective. Atoll Research Bulletin 543, 33-50.

Rogers, C.S., Garrison, V.H., 2001. Ten years after the crime: lasting effects of damage from a cruise ship anchor on a coral reef in St. John, U.S. Virgin Islands. Bulletin of Marine Science 69 (2), 793-803.

United States Coast Guard (USCG), 2006. United States Coast Guard Maritime Information Exchange Port State Information Exchange. $<$ http://cgmix.uscg.mil/psix/> (accessed 08.08.2006)

Western Pacific Fishery Management Council (WESPAC), 2006. Amendment to the Bottomfish and Seamount Groundfish Fishery Management Plan for the Hawaiian Archipelago. Honolulu, Hawaii, 221 pp. plus appendices.

\title{
Assessment of methylmercury production in a temperate salt marsh (Ria de Aveiro Lagoon, Portugal)
}

\author{
M. Válega ${ }^{\text {a,* }}$, A.I. Lillebø ${ }^{\text {a }}$, M.E. Pereira ${ }^{\text {a }}$, W.T. Corns ${ }^{\text {b }}$, P.B. Stockwell ${ }^{\text {, }}$, \\ A.C. Duarte ${ }^{\text {a }}$, M.A. Pardal ${ }^{c}$ \\ ${ }^{a}$ CESAM and Department of Chemistry, University of Aveiro, 3810-193 Aveiro, Portugal \\ ${ }^{\mathrm{b}}$ PSAnalytical Ltd, Arthur House, Crayfields Industrial Estate, Main Road, Orpington, Kent BR5 3HP, UK \\ c IMAR-Institute of Marine Research, Department of Zoology, University of Coimbra, 3004-517 Coimbra, Portugal
}

During the last two decades, restriction rules for the anthropogenic load of mercury have resulted in a substantial decrease of the inputs of this metal into aquatic systems. However the pool of mercury presently in sediments remains a problem due to its potential release to other environmental compartments such as the atmosphere, the overlying water column, and to living organisms through bioaccumulation and/or trophic transfer processes. The potential release of methylmercury from sediments to the overlying water column can harm the environment on a

\footnotetext{
* Corresponding author. Tel.: +351 234370 737; fax: +351234370084.

E-mail address: mvalega@ua.pt (M. Válega).
}

local or regional scale, particularly in areas highly dependent on fishery activities, endangering the system ecologically and economically as well as causing concern regarding human health.

The importance of salt marshes is recognised worldwide in providing essential ecological functions, such as hydrologic flux and storage, enhancement of metals accretion, high biological productivity, biogeochemical cycling and storage of contaminants, and habitat for fish and wildlife (Richardson, 1999; Mitsch and Gosselink, 2000). However, as transitional areas between land and sea, these ecotones can receive large inputs of pollutants. It is important to understand the mechanism of metals storage in salt marsh sediments and plants to avoid them becoming a metal 